\title{
Parameter Optimization and the Effect of Parameters on Mechanical Properties of Hybrid Composite
}

\author{
S. Senthil Murugan ${ }^{1}$, M.Velmurugan ${ }^{2}$, V. Jegan ${ }^{3}$ \\ ${ }^{1}$ Assistant Professor (Senior Grade), Mechanical Engg. Department, Mepco Schlenk Engineering, College, \\ Sivakasi Tamil Nadu, India \\ ${ }^{2}$ Assistant Professor, Mechanical Engg.Department, PSN Engineering College, Tirunelveli
}

Tamil Nadu, India

${ }^{3}$ Assistant Professor, Mechanical Engg. Department, S.Veerachamy Chettiar College of Engg. \& Tech., Tirunelveli, Tamil Nadu, India

*Corresponding Author: S. Senthil Murugan, Assistant Professor (Senior Grade), Mechanical Engg. Department, Mepco Schlenk Engineering, College, Sivakasi Tamil Nadu, India

\begin{abstract}
The properties of metal matrix composite can be influenced by the reinforcement particles at different weight fractions of the composite. In this work, the hybrid composite, which consists of Al.6061 as matrix and fly ash\&SiCP as the reinforcements, was processed by stir casting technique to studythe mechanical characterization and the effect of reinforcements (fly ash, SiCP)on the prepared composite. In addition, the study on the effect of input process parameters namely Wt.\% of SiC, Stirring time and Stirring speed on the tensile and compressive strength is achieved by Taguchi method for predicting the better parameters that gives the highest tensile and compressive strength to the casting.The contribution ratio is obtained using analysis of variance.
\end{abstract}

Keywords: HMMC, Stir casting, Taguchi method, ANOVA, DOE

\section{INTRODUCTION}

In recent times, aluminium and its alloys based composites have gained a lot of popularity in all the emerging fields of engineering and technology owing to their superior mechanical properties. Aluminium Metal Matrix Composites (AMMCs) combine the advantages of aluminium alloys and the special properties of ceramic particles like Silicon Carbide. Though these composites are light weight, they have good mechanical properties and the various reinforcements added with the matrix in Hybrid Metal Matrix Composites (HMMCs) improve the properties such as tensile strength, wear resistance and hardness etc... [1,2]. The stir casting, which is the liquid metallurgy technique used here, is economical, very easy of operation and convenient for mass production [3]. Although researchers have focused on the effect of process parameter on the mechanical properties of composites, not much research has been done using three process parameters like particle size of reinforcement, wt. $\%$ of reinforcement, and stirring time simultaneously while preparing the composites [4]. In this study, Taguchi technique, a Design of experiment (DOE) method, was used to improve the overall performances of the cast composite by optimizing the process parameter such as stirring time, stirring speed, increasing the wt $\% \mathrm{SiC}$ and the wt $\%$ of fly ash was kept constant.DOE is a technique for defining and investigating all possible conditions involving multiple factors, parameters and variables in an experiment. But wt. \% of reinforcement was the most influential parameter that obtains the highest mechanical characterization of the composite [5].

\section{DETAILS OF EXPERIMENTS}

\subsection{Composite Preparation}

In this study, the hybrid composite was fabricated with AA6061 alloy and the reinforcements SiC with 20 micron size $(5,10$, and 15\%) and fly ash (3\%) using stir casting method. Stir casting, the vortex technique, was used for fabricating the composites because of their simplicity and flexibility. 
The chemical composition of AA6061 matrix was analyzed by optical emission spectroscopy and the average values are given in table 1 . From the table, it is inferred that the ' $\mathrm{Mg}$ ' value is in between the range of minimum 0.8 and maximum $1.2 \mathrm{wt} . \%$. Similarly 'Si' value is also meeting the range min. $0.4 \%$ - max. $0.8 \%$ by weight.

Table1. Chemical composition of Al.6061

\begin{tabular}{|c|c|c|c|c|c|c|c|c|c|}
\hline Element & Al & $\mathbf{M g}$ & $\mathbf{S i}$ & $\mathbf{F e}$ & $\mathbf{C u}$ & $\mathbf{M n}$ & $\mathbf{C r}$ & $\mathbf{Z n}$ & $\mathbf{T i}$ \\
\hline Weight \% & 97.81 & 0.95 & 0.54 & 0.22 & 0.17 & 0.13 & 0.09 & 0.08 & 0.01 \\
\hline
\end{tabular}

Three different process parameters such as stirring time, stirring speed, and wt. \%of SiC were considered in the cast preparation. Figure 1 shows the stir casting set up used in this study. During the casting, the pouring temperature was maintained in the range of $740^{\circ} \mathrm{C}-810^{\circ} \mathrm{C}$ to obtain good cast ability. Here the degassing agent -solid dry Hexacholoroe thane $\left(\mathrm{C}_{2} \mathrm{Cl}_{6}\right)$-was used for the removal of dissolved gas in molten metal. The stirrer rod speed was maintained at 300, 350, and $400 \mathrm{rpm}$. Likewise, the reinforcements $\mathrm{SiC} \&$ fly ash (preheated at $300^{\circ} \mathrm{C}$ for 1 hour in an oven) were added into molten metal as per 5, 10 and $15 \% \mathrm{SiC} \& 3 \%$ fly ash wt. \% in the proposition of $\mathrm{gram} / \mathrm{min}$. Holding of AA6061-SiC-Flyash mixture is required for 5 minutes inside the furnace to have the homogeneous distribution of reinforcements throughout the matrix [6].Porosity in the composite was marginally lower because of the longer holding time after $\mathrm{SiC}$ addition. Solid-solution strengthening of the aluminium matrix is because of the small change in the silicon concentration resulting from the $\mathrm{Al}-\mathrm{SiC}$ chemical reaction, but it must indicate the enhanced interfacial bonding.

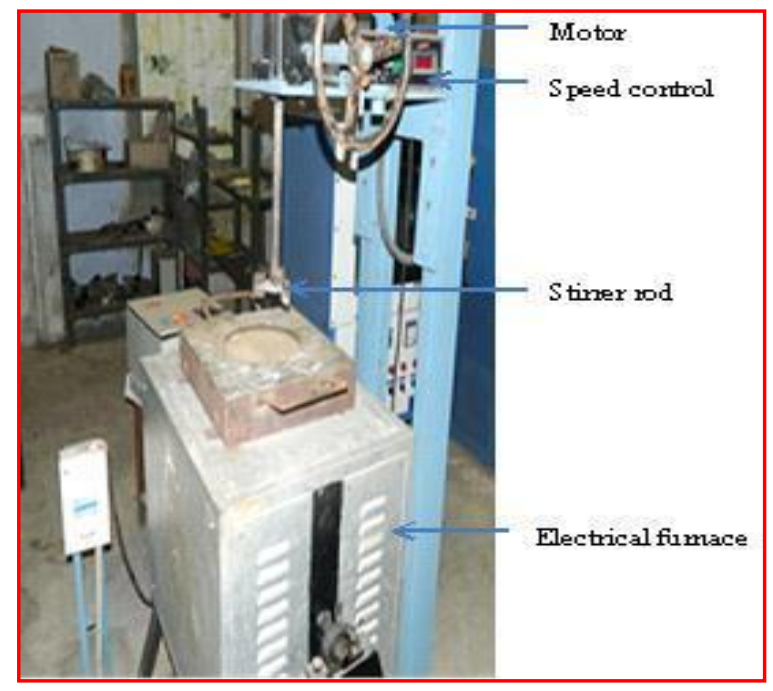

Fig1. Stir casting setup

In the next level, the specimens were prepared as per ASTM standards from casting for further mechanical characterization. The tensile and compressive strength of the resulting hybrid composite were measured using computerized universal testing machine (UTM) of maximum 5ton load and the stress-strain graph was noted down during the experiment. For each sample specimen, readings were taken as the response value for analysis using Taguchi method.

\subsection{Taguchi Technique}

Taguchi method combines the experimental and analytical concepts in order to determine the most influential parameter on the results. Owing to observe the degree of influencing of composite characteristic at the various levels, different process parameters such as stirring time, stirring speed and wt. \% SiC were taken. Each parameter was taken at three levels and is shown in table 2. A three level L9 orthogonal array with nine experimental runs were selected. In this research, nine different specimens were manufactured with the consideration of table 2 . The tensile and compressive strength of the prepared composite were tested in different treatment trails. The trail values can be taken as the response value in Taguchi.

Table2. Different process parameter and level

\begin{tabular}{|c|c|c|c|c|}
\hline Factor & Parameter(Units) & Level1 & Level2 & Level3 \\
\hline A & Stirring time(min) & 2 & 4 & 6 \\
\hline
\end{tabular}




\begin{tabular}{|c|c|c|c|c|}
\hline \multicolumn{5}{|c|}{} \\
\hline B & Stirring speed(rpm) & 300 & 350 & 400 \\
\hline C & Wt.,\% of SiC & 5 & 10 & 15 \\
\hline
\end{tabular}

Degree of freedom $(\mathrm{DOF})=\mathrm{N}-1$

Where, $N=$ number of level

For each factor, DOF equal to:

For stirring time $(\mathrm{A}): \mathrm{DOF}=3-1=2$

For stirring speed (B): DOF=3-1=2

For $\mathrm{Wt} \%$ of $\mathrm{SiC}(\mathrm{C}): \mathrm{DOF}=3-1=2$

Total DOF= No. ofexperiments-1

Total DOF for the experiment is $=9-1=8$

By varying three factors at three levels and conducting nine experiments, optimization is carried out. By using Taguchi method of optimization, the response variables like the compressive and tensile strength can be determined by means of Signal -to- Noise $(\mathrm{S} / \mathrm{N})$ ratio values. The tensile and compressive values of prepared composites were considered as the quality characteristic with the concept of "the large the better".

The $\mathrm{S} / \mathrm{N}$ ratio used for this response is given by

$\mathrm{S} / \mathrm{N}(\mathrm{dB})=-10 \log _{10}\left(1 / \mathrm{n} \sum_{\mathrm{i}=1}^{\mathrm{n}}\left(1 / \mathrm{y}_{\mathrm{i}}\right)^{2}\right)$

Where,

$\mathrm{dB}$-decibel, $\mathrm{y}$ - observation, $\mathrm{N}$-Total number of observation and $\mathrm{y}_{\mathrm{i}}$-response

\section{RESUlts AND DisCUSSION}

Micro structural study of prepared composite specimen is accomplished by SEM images at various compositions to analyses the uniform dispersions of reinforcement particulates over the matrix. The images of 50 micrometer are shown in figure $2 \mathrm{a}, \mathrm{b}$. The images are showing the uniform distribution of fly ash and silicon carbide over the matrix.

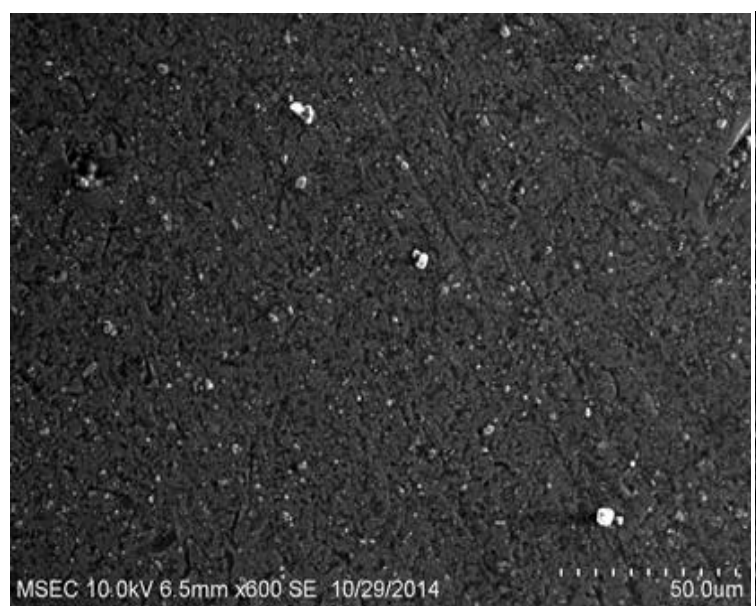

(a)

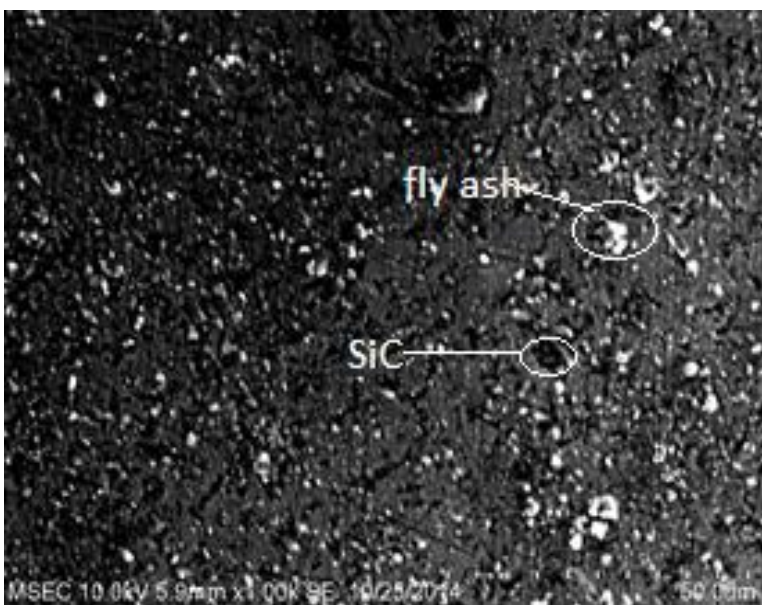

(b)

Fig2. SEM images of AMMC prepared

The presence of ceramic silicon carbide reinforcement leads to increase the tensile strength and compressive strength of the matrix. SiC dominates on the properties of composites due to its major content in the matrix compared to fly ash content. The tensile and compressive test specimens before and after testing are shown in the figures 3, 4 respectively. Trailvalues of the tensile and compressive Strength are given in table 3 and $\mathrm{S} / \mathrm{N}$ ratio values are available in table 4 . From the results, it is inferred that compressive strength is greater than the tensile strength; this is because of the ceramics properties nature of the silicon carbide. Results show the minimum tensile strength is $90 \mathrm{~N} / \mathrm{mm}^{2}$ at 2 minutes 300rpm and 5\% $\mathrm{SiC}$ and maximum value is $177 \mathrm{~N} / \mathrm{mm}^{2}$ at 6 minutes, $300 \mathrm{rpm}, 10 \% \mathrm{SiC}$ addition. Like this minimum and maximum compressive strength are $170 \mathrm{~N} / \mathrm{mm}^{2}, 203 \mathrm{~N} / \mathrm{mm}^{2}$ 
respectively. From this study, it is also know that optimum values of stirring time, stirring speed are required for the good composites.

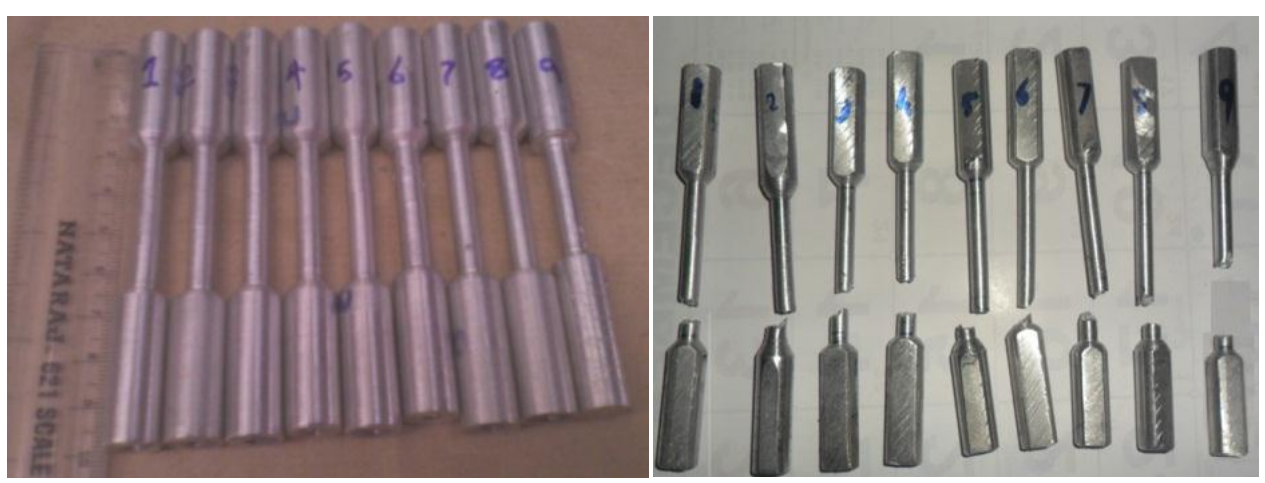

Fig3. Tensile test specimen before testing and after testing
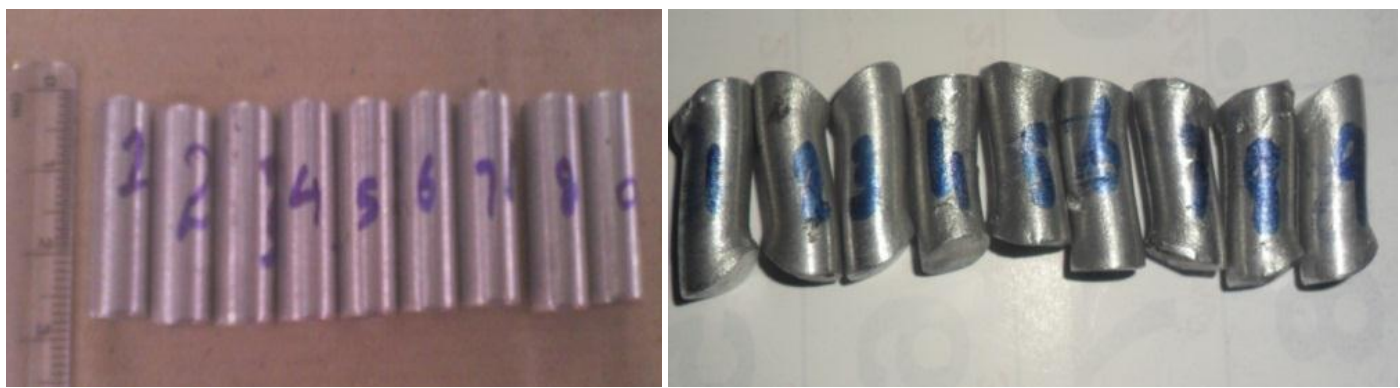

Fig4. Compressive test specimen before testing and after testing

Table3. Trail values of the Tensile and Compressive Strength

\begin{tabular}{|c|c|c|c|c|c|}
\hline $\begin{array}{l}\text { No. of } \\
\text { exp. }\end{array}$ & $\mathbf{A}$ & B & $\mathbf{C}$ & $\begin{array}{c}\text { Tensile } \\
\text { strength }\left(\mathrm{N} / \mathrm{mm}^{2}\right) \\
\end{array}$ & $\begin{array}{c}\text { Compressive } \\
\text { strength }\left(\mathrm{N} / \mathrm{mm}^{2}\right)\end{array}$ \\
\hline 1 & 2 & 300 & 5 & 90 & 170 \\
\hline 2 & 2 & 350 & 10 & 110 & 185 \\
\hline 3 & 2 & 400 & 15 & 130 & 197 \\
\hline 4 & 4 & 300 & 15 & 128 & 190 \\
\hline 5 & 4 & 350 & 5 & 94 & 175 \\
\hline 6 & 4 & 400 & 10 & 111 & 188 \\
\hline 7 & 6 & 300 & 10 & 177 & 203 \\
\hline 8 & 6 & 350 & 15 & 152 & 199 \\
\hline 9 & 6 & 400 & 5 & 103 & 182 \\
\hline
\end{tabular}

Table4. S/N ratio for Tensile and Compressive Strength

\begin{tabular}{|c|c|c|c|c|c|}
\hline \multirow[t]{2}{*}{ No. of exp. } & \multirow[t]{2}{*}{$\mathbf{A}$} & \multirow[t]{2}{*}{ B } & \multirow[t]{2}{*}{$\mathbf{C}$} & \multicolumn{2}{|c|}{$\mathrm{S} / \mathrm{N}$ ratio } \\
\hline & & & & $\begin{array}{c}\text { Tensile } \\
\text { strength }\left(\mathrm{N} / \mathrm{mm}^{2}\right)\end{array}$ & $\begin{array}{c}\text { Compressive } \\
\text { strength }\left(\mathrm{N} / \mathrm{mm}^{2}\right)\end{array}$ \\
\hline 1 & 2 & 300 & 5 & 39.08 & 44.60 \\
\hline 2 & 2 & 350 & 10 & 40.83 & 45.34 \\
\hline 3 & 2 & 400 & 15 & 42.27 & 45.88 \\
\hline 4 & 4 & 300 & 15 & 42.14 & 45.57 \\
\hline 5 & 4 & 350 & 5 & 39.46 & 44.86 \\
\hline 6 & 4 & 400 & 10 & 40.91 & 45.48 \\
\hline 7 & 6 & 300 & 10 & 44.96 & 46.15 \\
\hline 8 & 6 & 350 & 15 & 43.63 & 45.98 \\
\hline 9 & 6 & 400 & 5 & 40.26 & 45.20 \\
\hline
\end{tabular}

\subsection{Effect of Parameters on Tensile Strength}

The result shows that the effect of each parameter such as stirring time, speed, wt $\%$ of $\mathrm{SiC}$ at each level on the response. The average $\mathrm{S} / \mathrm{N}$ ratio shown in table 5 , of various parameters is obtained from table 4 and used for tensile strength of composite. The rank necessary of the different process factor in terms of their relative significance has been shown in table5. 
Table5. Effect of Various Parameters on Tensile Strength of Composite

\begin{tabular}{|c|c|c|c|}
\hline Parameter & Level 1 & Level 2 & Level 3 \\
\hline A & 40.72 & 40.83 & 42.95 \\
\hline B & 42.06 & 41.30 & 41.15 \\
\hline C & 39.60 & 42.23 & 42.68 \\
\hline
\end{tabular}

\section{Effect of wt. \% of silicon carbide (parameter ' $C$ ')}

The experimental results show that wt.\% of $\mathrm{SiC}$ is the most influential parameter that affects the tensile strength very strongly as compared to stirring speed, and stirring time because the content of $\mathrm{SiC}$ ceramic will make the bond with matrix thus creating strong strength. Figure 5 shows the effect of wt. \% SiC on Tensile Strength of the Composite. From the graph it is noted that addition of silicon carbide (SiC) from 5 to $15 \%$ increases $\mathrm{S} / \mathrm{N}$ ratio of tensile strength from 39.60 to 42.68 .

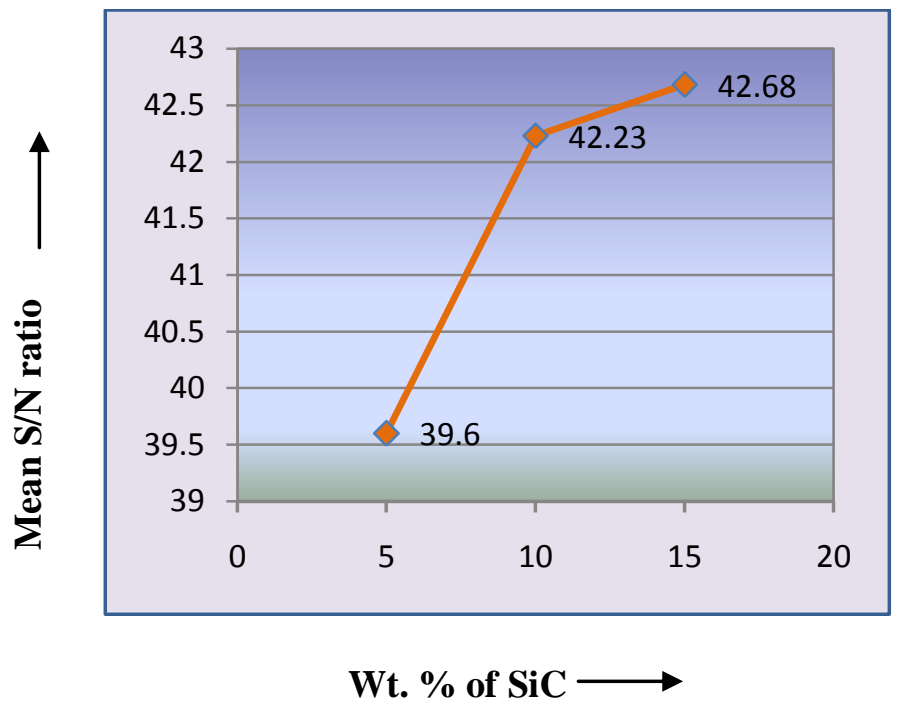

Fig5. Effect of wt. \% SiC on Tensile Strength of the Composite

\section{Effect of Stirring time (Parameter 'A')}

With increase in stirring time the tensile strength of composite increases continuously because of the distribution of reinforcement particles in the composite. As the Stirring time increases the mean S/N ratio for tensile strength increases from 40.72 to 42.95 . As the stirring time increases, the tensile strength of the composite increases continuously, in addition to, the silicon carbide particles distribute uniformly into matrix and homogeneity is also obtained by stirring the composite for 6 min. From S/N ratio, highest tensile strength 42.95 is achieved by stirring the reinforcement for 6 minutes after the addition of reinforcement completely into the matrix. Figure 6 furnishes the effect of stirring time on tensile strength of composite.

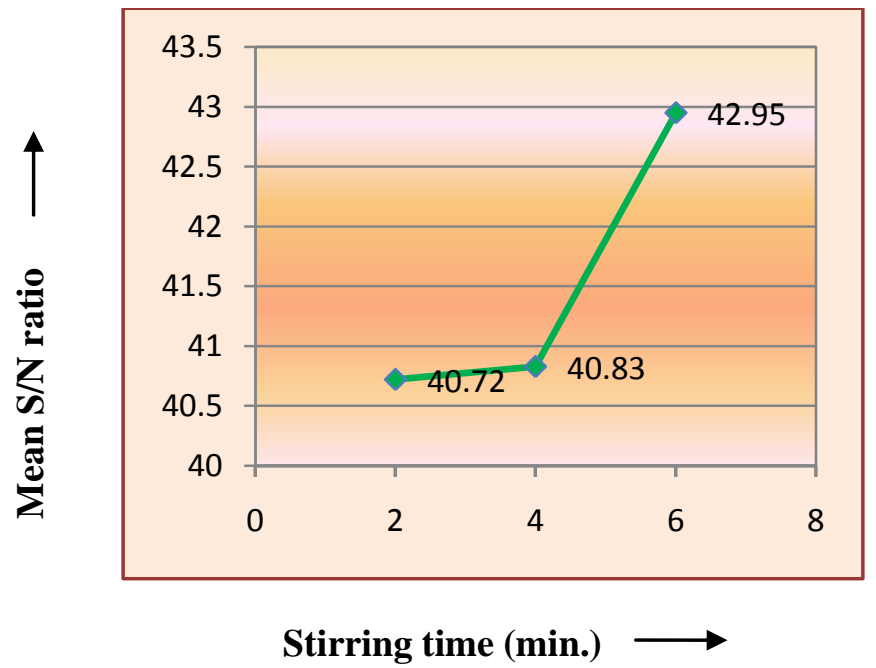

Fig6. Effect of stirring time on Tensile strength of composite 


\section{Effect of stirring speed (Parameter ' $B$ ')}

From the figure 7, which provides the details about the effect of stirring speed on the tensile strength, and the table 5, it is inferred that when the stirring speed increases from $300 \mathrm{rpm}$ to $400 \mathrm{rpm}$ the corresponding mean $\mathrm{S} / \mathrm{N}$ ratio decreases from the value 42.06 to 41.15 .

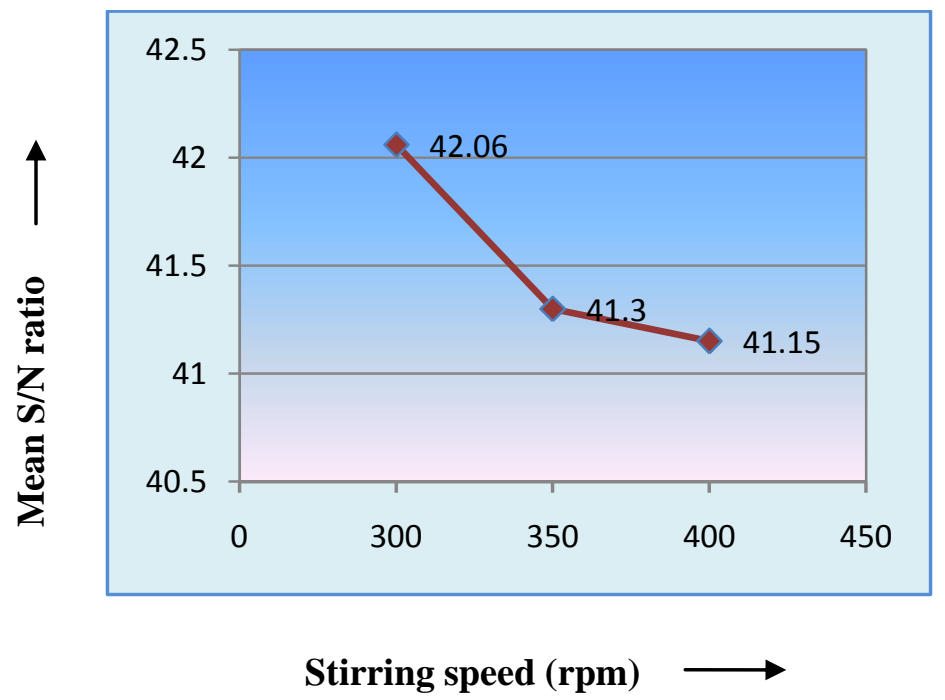

Fig7. Effect of Stirring Speed on Tensile Strength of Composite

\section{Pareto ANOVA}

The purpose of ANOVA is to investigate the parameters at different level of composite combination and to find whether the total variation is significant or not. The Pareto values are given in table 6 .

Table6. Pareto ANOVA

\begin{tabular}{|c|c|c|c|c|c|c|}
\hline Factors & & A & B & C & E & Total \\
\hline \multirow{2}{*}{$\begin{array}{c}\text { Sum at factor } \\
\text { level }\end{array}$} & 1 & $\sum \mathrm{A}_{1}$ & $\sum \mathrm{B}_{1}$ & $\sum \mathrm{C}_{1}$ & $\sum \mathrm{E}_{1}$ & $\mathrm{~T}$ \\
\cline { 2 - 7 } & 2 & $\sum \mathrm{A}_{2}$ & $\sum \mathrm{B}_{2}$ & $\sum \mathrm{C}_{2}$ & $\sum \mathrm{E}_{2}$ \\
\cline { 2 - 7 } & 3 & $\sum \mathrm{A}_{3}$ & $\sum \mathrm{B}_{3}$ & $\sum \mathrm{C}_{3}$ & $\sum \mathrm{E}_{3}$ & $\mathrm{ST}$ \\
\hline $\begin{array}{c}\text { Sum of } \\
\text { squares of } \\
\text { Differences }\end{array}$ & $\mathrm{SA}$ & $\mathrm{SB}$ & $\mathrm{SC}$ & $\mathrm{SE}$ & 8 \\
\hline $\begin{array}{c}\text { Degrees of } \\
\text { freedom }\end{array}$ & & 2 & 2 & 2 & 2 & 1 \\
\hline $\begin{array}{c}\text { Contribution } \\
\text { ratio }\end{array}$ & & $\mathrm{S}_{\mathrm{A}} / \mathrm{S}_{\mathrm{T}}$ & $\mathrm{S}_{\mathrm{B}} / \mathrm{S}_{\mathrm{T}}$ & $\mathrm{S}_{\mathrm{C}} / \mathrm{S}_{\mathrm{T}}$ & $\mathrm{S}_{\mathrm{E}} / \mathrm{S}_{\mathrm{T}}$ & \\
\hline
\end{tabular}

$\mathrm{T}=\sum \mathrm{A}_{1}+\sum \mathrm{A}_{2}+\sum \mathrm{A}_{3}$

$\mathrm{S}_{\mathrm{A}}=\left(\sum \mathrm{A}_{1}-\sum \mathrm{A}_{2}\right)^{2}+\left(\sum \mathrm{A}_{1}-\sum \mathrm{A}_{3}\right)^{2}+\left(\sum \mathrm{A}_{2}-\sum \mathrm{A}_{3}\right)^{2}$

$\mathrm{S}_{\mathrm{B}}=\left(\sum \mathrm{B}_{1}-\sum \mathrm{B}_{2}\right)^{2}+\left(\sum \mathrm{B}_{1}-\sum \mathrm{B}_{3}\right)^{2}+\left(\sum \mathrm{B}_{2}-\sum \mathrm{B}_{3}\right)^{2}$

$\mathrm{S}_{\mathrm{C}}=\left(\sum \mathrm{C}_{1}-\sum \mathrm{C}_{2}\right)^{2}+\left(\sum \mathrm{C}_{1}-\sum \mathrm{C}_{3}\right)^{2}+\left(\sum \mathrm{C}_{2}-\sum \mathrm{C}_{3}\right)^{2}$

$\mathrm{S}_{\mathrm{E}}=\left(\sum \mathrm{E}_{1}-\sum \mathrm{E}_{2}\right)^{2}+\left(\sum \mathrm{E}_{1}-\sum \mathrm{E}_{3}\right)^{2}+\left(\sum \mathrm{E}_{2}-\sum \mathrm{E}_{3}\right)^{2}$

$\mathrm{S}_{\mathrm{T}}=\mathrm{S}_{\mathrm{A}}+\mathrm{S}_{\mathrm{B}}+\mathrm{S}_{\mathrm{C}}+\mathrm{S}_{\mathrm{E}}$

Analysis of variance (ANOVA) for Tensile Strength of composites

ANOVA was applied to study the contribution of all parameters. Table 7 shows the ANOVA results for the $\mathrm{S} / \mathrm{N}$ ratio for the Tensile strength of the composite

Table7. ANOVA results

\begin{tabular}{|c|c|c|c|c|c|}
\hline Source & SFL & SSD & DOF & Cont. ratio & Opt. level \\
\hline \multirow[t]{3}{*}{ A } & 122.18 & \multirow{3}{*}{84.78} & \multirow[t]{3}{*}{2} & \multirow{3}{*}{31.51} & \multirow{3}{*}{ A3 } \\
\hline & 122.51 & & & & \\
\hline & 128.85 & & & & \\
\hline \multirow[t]{3}{*}{ B } & 126.18 & \multirow[t]{3}{*}{13.14} & \multirow[t]{3}{*}{2} & \multirow[t]{3}{*}{4.88} & \multirow[t]{3}{*}{ B1 } \\
\hline & 123.92 & & & & \\
\hline & 123.44 & & & & \\
\hline
\end{tabular}




\begin{tabular}{|c|c|c|c|c|c|}
\hline \multirow[t]{3}{*}{$\mathrm{C}$} & 118.80 & \multirow[t]{3}{*}{149.58} & \multirow[t]{3}{*}{2} & \multirow[t]{3}{*}{55.59} & \multirow[t]{3}{*}{$\mathrm{C}_{3}$} \\
\hline & 126.70 & & & & \\
\hline & 128.04 & & & & \\
\hline \multirow[t]{3}{*}{ Error } & 123.67 & \multirow[t]{3}{*}{21.54} & \multirow[t]{3}{*}{2} & \multirow[t]{3}{*}{8.02} & \multirow[t]{3}{*}{-} \\
\hline & 123.23 & & & & \\
\hline & 126.69 & & & & \\
\hline Total & 373.54 & 269.06 & 8 & 100 & - \\
\hline
\end{tabular}

SFL: Sum at factor level,

SSD: sum of the square difference,

Cont. ratio: contribution ratio,

Opt. Level: optimization level,

By considering the contribution ratio from the table 7, it is identified that the highest contribution of wt. \% SiC reinforcement (parameter 'C') signifies the value of 55.59 in the tensile strength of the prepared composites. Next, stirring time showed its contribution up to 31.51. The contribution ratio of stirring speed isthe least of about 4.88 .

\subsection{Effect of Various Parameters on Compressive Strength of Composite}

The mean $\mathrm{S} / \mathrm{N}$ ratio for level 1,2 and 3 can be calculated by taking the average of the $\mathrm{S} / \mathrm{N}$ ratio for the experiment 1-3, 3-6 and 6-9. The effect of each parameter at each level on the response is identified by the mean (or Average) $\mathrm{S} / \mathrm{N}$ value of the compressive strength of the prepared composite. Table 8 shows the $\mathrm{S} / \mathrm{N}$ ratio of compressive strength of the composites, which are calculated from the $\mathrm{S} / \mathrm{N}$ ratio of compressive strength available in table 4 . From $\mathrm{S} / \mathrm{N}$ ratio it is cleared that each parameter has different effect on compressive strength of metal matrix composite.

Table8. Effect of various parameters on Compressive Strength of composite

\begin{tabular}{|c|c|c|c|}
\hline Parameter & Level 1 & Level 2 & Level 3 \\
\hline A & 45.27 & 45.30 & 45.77 \\
\hline B & 45.44 & 45.39 & 45.52 \\
\hline C & 44.88 & 45.65 & 45.81 \\
\hline
\end{tabular}

\section{Effect of wt. \% of silicon (Parameter ' $C$ ')}

$\mathrm{Wt} \%$ of reinforcement is the main parameter that affects the compressive strength of the composite. Figure 8 shows the relation of $\mathrm{S} / \mathrm{N}$ ratio and $\mathrm{Wt}$. \% of SiC. From figure 8 , it is observed that when the wt. \% of Sic reinforcement increases from 5 to $15 \%$, the S/N ratio for compressive strength increases from 44.88 to 45.81 . Thus it is the most influential parameter that affects the compressive strength very strongly as compared to stirring time and stirring speed. In $\mathrm{S} / \mathrm{N}$ ratio, highest compressive strength 45.81 is achieved at $15 \mathrm{wt}$. \% of $\mathrm{SiC}$ of composites.

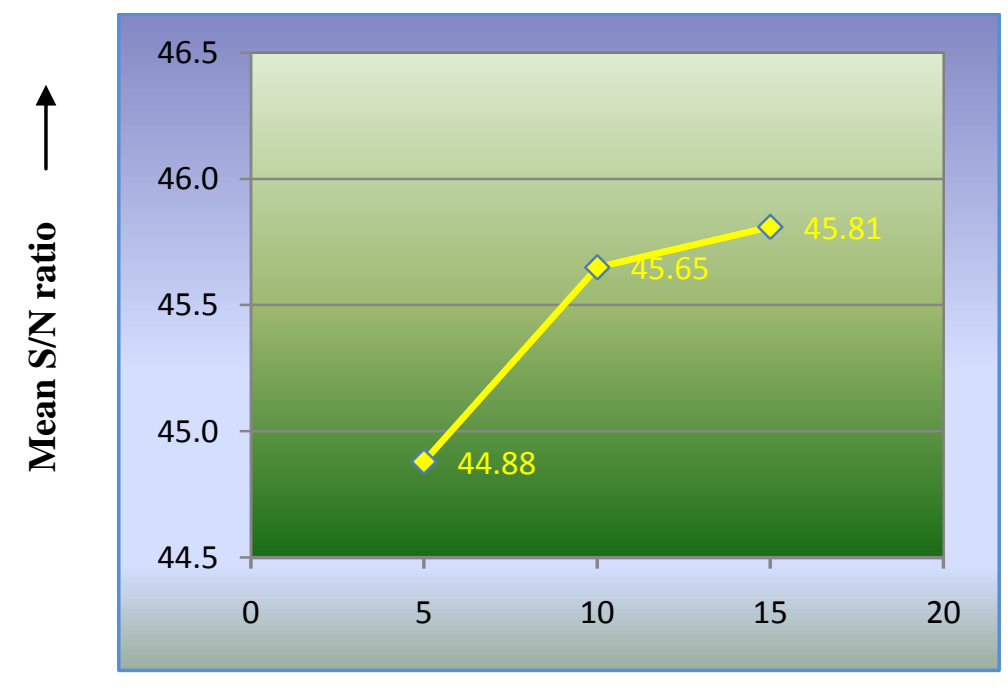

Wt. \% of $\mathrm{SiC}$

Fig8. Effect of wt. \% SiC on compressive Strength 


\section{Effect of Stirring time (Parameter 'A')}

As the stirring time increases from 2 to 6 minutes, the compressive Strength of the composite increases continuously because of the distribution of reinforcement particles in the composite and making homogeneity and the mean $\mathrm{S} / \mathrm{N}$ ratio for compressive strength increases from 45.27 to 45.77.That is inferred in figure 9 . From the $\mathrm{S} / \mathrm{N}$ ratio values, the highest compressive strength 45.77 is achieved at 6 minutes of the effect on stirring time of composite.

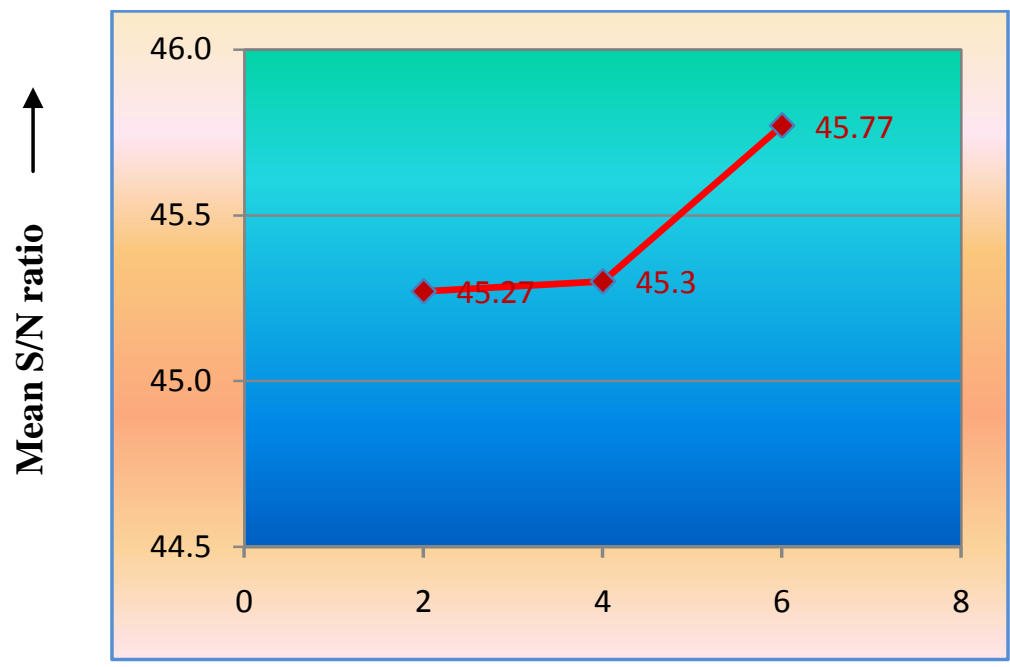

Stirring time (min.)

Fig9. Effect of stirring time on compressive strength

\section{Effect of stirring speed (Parameter ' $B$ ')}

The Figure 10 shows the graph of effect of stirring speed on compressive strength of the prepared composite. The $\mathrm{X}$-axis denotes stirring speed and the $\mathrm{Y}$-axis is for mean $\mathrm{S} / \mathrm{N}$ raio values. The result showed that when stirring speed increases, compressive strength of composite decreases initially and the value reaches up to 45.39 at $350 \mathrm{rpm}$ and further increasesupto 45.52 at $400 \mathrm{rpm}$. Thus, in S/N ratio, the highest compressive strength 45.52 is obtained at $400 \mathrm{rpm}$.

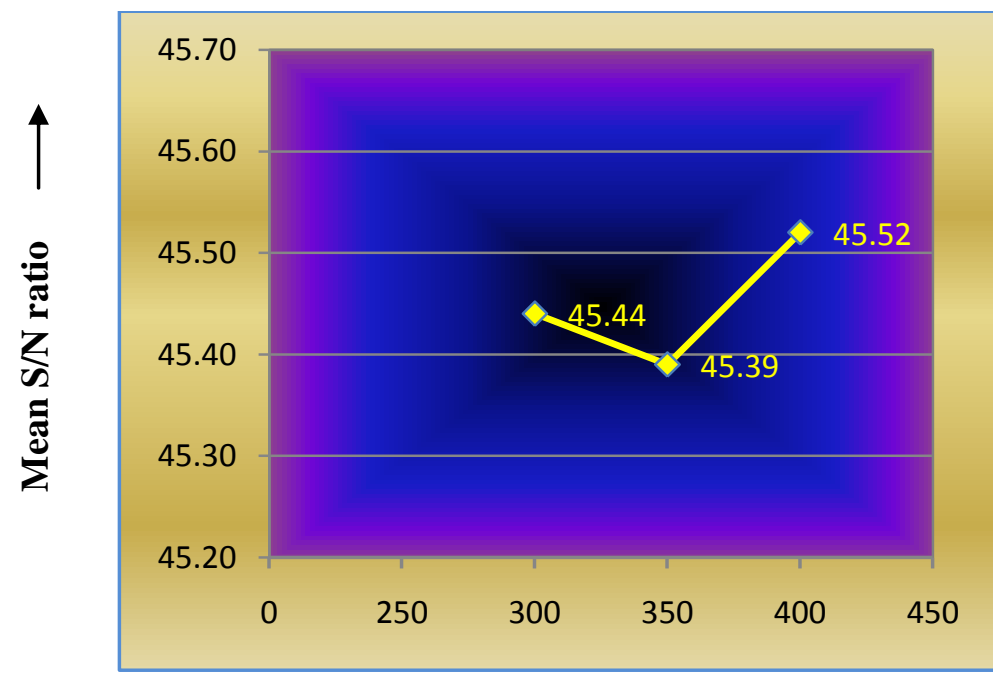

Stirring speed (rpm) $\longrightarrow$

Fig10. Effect of stirring speed on compressive strength of composite

\section{Analysis of variance (ANOVA) for Compressive Strength of composites}

ANOVA was applied to study the contribution of all parameters. Table 9 provides the details about the ANOVA results for the $\mathrm{S} / \mathrm{N}$ ratio of compressive strength of the prepared composites. 
Table9. ANOVA results for the $S / N$ ratio for the compressive strength of the composite

\begin{tabular}{|c|c|c|c|c|c|}
\hline Source & SFL & SSD & DOF & Cont. ratio & Opt. level \\
\hline \multirow[t]{3}{*}{$\mathrm{A}$} & 135.82 & \multirow[t]{3}{*}{4.304} & \multirow[t]{3}{*}{2} & \multirow[t]{3}{*}{22.60} & \multirow[t]{3}{*}{ A3 } \\
\hline & 135.91 & & & & \\
\hline & 137.33 & & & & \\
\hline \multirow[t]{3}{*}{ B } & 136.32 & \multirow[t]{3}{*}{0.221} & \multirow[t]{3}{*}{2} & \multirow[t]{3}{*}{1.16} & \multirow[t]{3}{*}{ B1 } \\
\hline & 136.18 & & & & \\
\hline & 136.86 & & & & \\
\hline \multirow[t]{3}{*}{$\mathrm{C}$} & 134.66 & \multirow[t]{3}{*}{13.22} & \multirow[t]{3}{*}{2} & \multirow[t]{3}{*}{69.41} & \multirow[t]{3}{*}{$\mathrm{C}_{3}$} \\
\hline & 136.97 & & & & \\
\hline & 137.43 & & & & \\
\hline \multirow[t]{3}{*}{ Error } & 136.06 & \multirow[t]{3}{*}{1.299} & \multirow[t]{3}{*}{2} & \multirow[t]{3}{*}{6.83} & \multirow[t]{3}{*}{-} \\
\hline & 136.11 & & & & \\
\hline & 136.89 & & & & \\
\hline Total & 409.06 & 19.046 & 8 & 100 & - \\
\hline
\end{tabular}

The table 9 infers that the wt. \% SiC signifies the highest contribution in compressive strength of the composite prepared, which is around $69.41 \%$. After that, stirring time contribution is $22.60 \%$. At last stirring speed shows its least contribution of $1.16 \%$ in the compressive Strength.

\section{CONCLusion}

Hybrid composite reinforced with $\mathrm{SiC}$ and fly ash is successfully fabricated by liquid metallurgy technique process at different levels. Parameters such as wt. \% of SiC $(5,10 \& 15 \%)$, stirring time (2, $4 \& 6 \mathrm{~min})$, stirring speed $(300,350 \& 400 \mathrm{rpm})$ were varied to cast the required specimens. The result showed that the tensile strength value increases with the increase in wt. \% of SiC and stirring time and tensile strength decreases with the decrease in stirring speed. The maximum and minimum tensile strength values obtained are $90 \mathrm{~N} / \mathrm{mm}^{2}, 177 \mathrm{~N} / \mathrm{mm}^{2}$ respectively. Similarly, by varying the composition, the maximum and minimum compressive strength values were noted as $170 \mathrm{~N} / \mathrm{mm}^{2}$ to $203 \mathrm{~N} / \mathrm{mm}^{2}$ respectively. S/N ratios for different experiment were also estimated to determine the optimum response variable.

ANOVA technique was used for determining contribution ratio of each parameter in tensile and compressive strength of the composite. To prepare the good composite, the parameters chosen as per contribution ratio are stirring time 6 minutes, stirring speed $300 \mathrm{rpm}$ and 15\% of SiC. From the Pareto analysis, it is evident that the $\mathrm{wt} \%$ of $\mathrm{SiC}$ is a major contribution factor for improving the tensile and compressive strength. The range of $\mathrm{S} / \mathrm{N}$ ratio for tensile strength is between 39.60 and 42.95 . Likewise, the range of $\mathrm{S} / \mathrm{N}$ ratio for compressive strength is between 44.88 and 45.81 .

\section{REFERENCES}

[1] Lakhvir Singh, Baljinder Ram, and Amandeep Singh (2013). "Optimization of process parameter for stir casted Aluminium metal matrix composite using Taguchi method", International Journal of Research in Engineering and Technology, Vol. 02, PP-375.

[2] Osama S. Muhammed, Haitham R. Saleh, and Hussam L. Alwan (2008) "Using of Taguchi Method to Optimize the Casting of Al-Si/ $/ \mathrm{Al}_{2} \mathrm{O}_{3}$ Composites", Eng\& Tech. Journal, Vol. 02, PP-1143-1150.

[3] ShouvikGhosh, PrasantaSahoo, and Goutam Sutradhar (2012) "Wear Behaviour of Al-SiC $\mathrm{C}_{\mathrm{P}}$ Metal Matrix Composites And Optimization Using Taguchi Method And Grey Relational Analysis", Journal of Minerals and Materials Characterization and Engineering, Vol.11, PP-1085-1094.

[4] Gopal Krishna UB, Sreenivas Rao KV and Vasudeva B (2013) "Effect of Boron Carbide Reinforcement of Aluminium Matrix Composites", International Journal Of Metallurgical \& Materials, Vol. 3, PP.41-48.

[5] David Raja Selvam.J, Robinson Smart.D.S, andDinaharan,(2013) "Microstructure and Some Mechanical Properties of Fly Ash Particulate Reinforced AA6061 Aluminium Alloy Composite Prepared by Compo Casting", Materials and Science, Vol. 49, pp. 28-34.

[6] Tham.L.M, Gupta.M, Cheng.L(2001) "Effect Of Limited Matrix-Reinforcement Interfacial Reaction On Enhancing The Mechanical Properties Of Aluminium-Silicon Carbide Composites" Acta Materilia, Elsevier, Vol.49, pp-3243-3253. 


\section{AUTHORS' BIOGRAPHY}

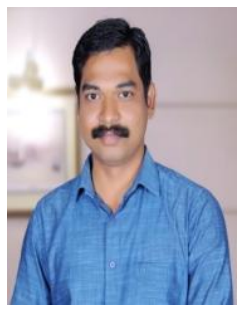

Mr. S. Senthil Murugan, is currently working as Assistant Professor (Senior Grade) in the Department of Mechanical Engineering, Mepco Schlenk Engineering College, Sivakasi and pursuing Ph.D at NIT, Trichy. He has published around 33 research articles in various conferences and journals. He guided more than 35 PG degree students in various projects such as design and fabrication projects, hazard evaluations and university phase I \& II projects and 13 UG degree students. He had undergone summer faculty research fellowship at IIT Delhi. He organized 5 various programmes in national level. He is acting as an editorial board member and the reviewers in various journals. He attended 23 workshops/QIPs in various institutions. He is involving in two govt. funded (MSME) projects. He is the member of Indian Institute of Metals and Indian Society for Technical Education. His areas of interests are welding, metal matrix composite, environmental safety etc.

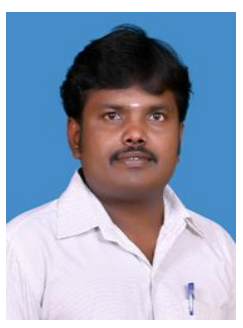

Mr. M. Velmurugan, is currently working as Assistant Professor in the Department of Mechanical Engineering, PSN Engineering College, Tirunelveli, Tamilnadu. He completed his M.E. degree at Mepco Schlenk Engineering College, Sivakasi. He has published 6 research articles in various conferences and journals. His area of interests includes composites, casting, CAD modeling.

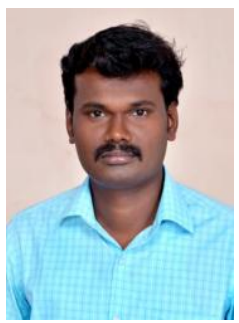

V. Jegan, is currently working as Assistant Professor in the Department of Mechanical Eng., S.Veerachamy Chettiar College of Engg. \& Tech., Tirunelveli, Tamilnadu. He completed his M.E. degree at Mepco Schlenk Engineering College, Sivakasi. He has published 7 research articles in various conferences and journals. His area of interests includes composites, casting, CAD modelling \& Design.

Citation: S. Senthil Murugan et al, (2018). Parameter Optimization and the Effect of Parameters on Mechanical Properties of Hybrid Composite, International Journal of Modern Studies in Mechanical Engineering (IJMSME), 4(1), pp.1-10, DOI: http://dx.doi.org/10.20431/2454-9711.0401001.

Copyright: () 2018 S. Senthil Murugan. This is an open-access article distributed under the terms of the Creative Commons Attribution License, which permits unrestricted use, distribution, and reproduction in any medium, provided the original author and source are credited 